\title{
A Genetic Method for Selective and Quickly Reversible Silencing of Mammalian Neurons
}

\author{
Hilde A. E. Lechner, Edward S. Lein, and Edward M. Callaway \\ Systems Neurobiology Laboratories, The Salk Institute, La Jolla, California 92037
}

Genetic methods for neuronal silencing have great promise for allowing selective inactivation of specific cell types within complex neural systems. Present methods, however, are limited in their reversibility by the slow time scale (days) of transcriptional regulation. We report the rapid and reversible inactivation of mammalian cortical neurons expressing the insect G-proteincoupled receptor AlstR (Drosophila allatostatin receptor) after application of its peptide ligand allatostatin $(A L)$. The onset and reversal of inactivation could be achieved rapidly, within minutes. Moreover, the effects of $A L$ were selective for AlstRtransfected neurons. The AlstR/AL system is therefore a promising genetic method for selective and quickly reversible silencing of neuronal activity.

Key words: AlstR; allatostatin; GIRK; neural silencing; insect receptor; cortical neurons
Historically, relating neural circuits to perception and behavior has relied heavily on the inactivation of neurons with reversible or irreversible lesion techniques. Conventional inactivation techniques, however, are of limited utility, because even very small regions of neural tissue contain many types of neurons and dendritic and axonal processes that are physically and functionally intertwined. Studies of neural circuits have indicated that different cell types within a single structure have unique patterns of connectivity and play unique roles in information processing (Zemelman and Miesenböck, 2001). Therefore, to relate cellular brain structure to function it is necessary to manipulate neural circuits at the level of individual cell types. Several genetic techniques are currently being developed that use cell typespecific promoters to restrict gene expression to cells of interest (Zemelman and Miesenböck, 2001). For example, Yoshida et al. (2001) have developed a cell type-specific permanent lesion technique by targeting immunotoxins to retinal starburst amacrine cells that express an antigen under the control of the metabotropic glutamate receptor 2 promoter.

An ideal method for inactivation would be not only genetic in nature, to allow for targeting of a specific cell type, but would also allow for reversible manipulation of neural activity on a fast time scale. One potential technique for quickly reversible inactivation is to use G-protein-coupled receptors that activate G-proteincoupled inwardly rectifying K (GIRK) channels (Dascal, 1997; Coward et al., 1998; Redfern et al., 1999; Mark and Herlitze, 2000), thereby hyperpolarizing the cell membrane and silencing neural activity. For example, a modified opiate receptor (Coward et al., 1998) that activates GIRK channels and is activated selectively by a synthetic ligand has been used successfully to slow the heart rate of transgenic mice expressing the receptor (Redfern et

Received Feb. 20, 2002; revised April 2, 2002; accepted April 10, 2002.

This work was supported by a grant from the David and Lucile Packard Foundation. E.S.L. is supported by the Howard Hughes Medical Institute. We thank H.-J. Kreienkamp (University of Hamburg, Hamburg, Germany) for kindly providing the AlstR plasmid.

Correspondence should be addressed to Hilde A. E. Lechner, Systems Neurobiology Laboratories-C, The Salk Institute, 10010 North Torrey Pines Road, La Jolla, CA 92037. E-mail: lechner@salk.edu.

Copyright (C) 2002 Society for Neuroscience $\quad 0270-6474 / 02 / 225287-04 \$ 15.00 / 0$ al., 1999). In addition to binding RASSL, however, the synthetic ligand binds to endogenous mammalian opiate receptors, which restricts its application to non-neural systems. To manipulate activity selectively in the brain using G-protein-coupled receptors, the receptor should be activated only by a specific ligand that does not cross-react with other endogenous receptors.

The Drosophila allatostatin receptor (AlstR) (Birgül et al., 1999) meets many of the criteria mentioned above, and was thus tested as a possible candidate for silencing mammalian neurons reversibly on a fast time scale. AlstR is a G-protein-coupled receptor involved in the regulation of juvenile hormone synthesis in insects. It is activated by the insect peptide allatostatin (AL; Ser-Arg-Pro-Tyr-Ser-Phe-Gly-Leu- $\mathrm{NH}_{2}$ ) and is not activated by the ligands of related mammalian receptors (e.g., somatostatin, galanin, enkephalins, and proctolin) (Birgül et al., 1999). Nevertheless, AlstR has been shown to activate mammalian GIRK channels via $G_{i / o}$ proteins in Xenopus oocytes (Birgül et al., 1999). Here we show that the AlstR/AL receptor/ligand system can be used to silence activity in cortical neurons quickly and reversibly. We also show that this effect is selective for neurons that express AlstR. Neurons that do not express the receptor are unaffected by AL, suggesting that the AL does not cross-react with endogenous receptors of cortical neurons.

\section{MATERIALS AND METHODS}

Tissue culture. Brain slices were prepared from the visual cortex of 13- to 30-d-old ferrets as described previously (McAllister et al., 1995; Dantzker and Callaway, 1998). Briefly, animals were deeply anesthetized with sodium pentobarbitol $(100 \mathrm{mg} / \mathrm{kg}$, i.p. $)$ and decapitated. Brains were extracted under sterile conditions and submerged in $4^{\circ} \mathrm{C}$ HEPESbuffered artificial CSF (ACSF) (in mM): $140 \mathrm{NaCl}, 5 \mathrm{KCl}, 1 \mathrm{MgCl}_{2}, 24$ dextrose, $10 \mathrm{HEPES}$, and $1 \mathrm{CaCl}_{2}, \mathrm{pH}$ 7.4. After the pia was removed, the visual cortex was cut into $400 \mu \mathrm{m}$ parasagittal slices using a tissue slicer (Katz, 1987). Slices were then transferred onto cell-culture inserts $(0.4 \mu \mathrm{m}$ pore size; Falcon, Franklin Lakes, NJ) in six well culture dishes and fed with medium from below. The medium was composed of $50 \%$ basal Eagle's medium without glutamine, 25\% HBSS, $330 \mathrm{~mm}$ dextrose, $10 \mathrm{~mm}$ HEPES, $200 \mathrm{mM}$ L-glutamine, $10 \mathrm{U} / \mathrm{ml}$ penicillin-streptomycin (all from Invitrogen, San Diego, CA), and 25\% horse serum (Hyclone, Logan, UT). Slices were then transfected using the Helios Gene Gun (Bio-Rad, Hercules, CA) and incubated in $5 \% \mathrm{CO}_{2}$ at $37^{\circ} \mathrm{C}$ for $1 \mathrm{~d}$ before recording. Similar procedures using rat brain tissue did not result in healthy slices. 
Gene gun DNA transfer. Gold microcarriers (1.6 $\mu \mathrm{m}$ diameter; Bio$\mathrm{Rad})$ were coated with vector DNA at a concentration of $60 \mu \mathrm{g}$ of DNA per $12.5 \mathrm{mg}$ of gold, according to the supplier's instructions. The following plasmids were used (in $\mu \mathrm{g}$ ): controls: 20 pEGFP-N1 (Clontech, Palo Alto, CA), 20 pcDNA3.1-GIRK1 (Dascal et al., 1993), and 20 pcDNA3.1GIRK2 (Lesage et al., 1994); experimental: 15 pcDNA3.1-AlstR (Birgül et al., 1999), 15 pEGFP-N1, 15 pcDNA3.1-GIRK1, and 15 pcDNA3.1GIRK2. All transgenes were expressed under the control of a cytomegalovirus immediate-early promoter. Slices were shot at 90-100 psi. Cotransfection using gold particles coated with multiple plasmids has been reported to be nearly $100 \%$ (Arnold et al., 1994). Thus, green fluorescent protein (GFP)-labeled neurons were assumed to also express the allatostatin receptor and/or the GIRK channel subunits.

Recording. Cells were recorded $24-48 \mathrm{hr}$ after transfection. Patch electrodes (8-14 M $\Omega$ resistance) filled with (in mM): $140 \mathrm{~K}$-gluconate, 8 $\mathrm{NaCl}, 10 \mathrm{HEPES}, 1.3$ EGTA, 2 ATP, and $0.3 \mathrm{GTP}, \mathrm{pH} 7.7$, along with 285 mOsm $\mathrm{KOH}$, were used for whole-cell current-clamp recordings. Slices were perfused with $\mathrm{ACSF}$ (in mM): $124 \mathrm{NaCl}, 5 \mathrm{KCl}, 1.3 \mathrm{MgSO}_{4}$, $26 \mathrm{NaHCO}_{3}, 2.5 \mathrm{CaCl}_{2}, 1.0 \mathrm{NaH}_{2} \mathrm{PO}_{4}$, and 11 dextrose at room temperature. The peptide AL (Ser-Arg-Pro-Tyr-Ser-Phe-Gly-Leu-N $\mathrm{H}_{2} ; 1 \mathrm{~nm}$ in ACSF) was applied by perfusion at a rate of $\sim 800 \mu \mathrm{l} / \mathrm{min}$. AL was washed out by replacement with normal ACSF at a flow rate of $\sim 200$ $\mu \mathrm{l} / \mathrm{min}$, corresponding to a complete exchange of the bath volume $(3 \mathrm{ml})$ every $15 \mathrm{~min}$. Physiological measures before, after $8 \mathrm{~min}$ of perfusion with AL, and 15-20 min after washout were compared.

\section{RESULTS}

AlstR was expressed in neonatal [postnatal day 13 (P13) to P30] ferret visual cortex slices using "Biolistics" particle-mediated gene transfer. Neurons were transfected with AlstR, GIRK channel subunits 1 and 2 (Dascal, 1997; Mark and Herlitze, 2000), and enhanced GFP (EGFP). Control neurons were transfected with GIRK1, GIRK2, and EGFP. The overexpression of GIRK channel subunits was necessary, because their natural expression is under developmental regulation. Newborn cortical neurons of mice do not reach adult levels of GIRK channel expression before P10 (Chen et al., 1997), and expression is likely to be further delayed in the more slowly developing ferret cortex. Indeed, neonatal cortical neurons of the ferret did not respond to the $\mathrm{GABA}_{\beta}$ agonist baclofen (data not shown), suggesting that GIRK channels were not yet expressed at sufficient levels. At 24-36 hr after transfection, the membrane potential, input resistance, and excitability (current required to reach spike threshold) of AlstR-transfected and control neurons were determined before, during, and after addition of $1 \mathrm{nM}$ allatostatin to the bath (Fig. $1 A, B$ ).

\section{Specificity of AL-induced effects}

Before perfusion with AL, AlstR-transfected neurons and control cells did not differ in resting membrane potential, input resistance, or excitability (Table 1). After application of AL, however, AlstR-transfected neurons were quickly hyperpolarized, whereas untransfected neurons remained unaffected (Fig. 1). In AlstRtransfected cells, application of $1 \mathrm{nM}$ AL produced a change in resting membrane potential of $-6.7 \pm 0.7 \mathrm{mV}$ compared with baseline values $(n=15 ; p<0.0001)$, and a decrease in input resistance to $48 \pm 7 \%$ of the initial value $(n=15 ; p<0.001)$ within several minutes (Fig. 2A1,2). Control cells showed no change in resting membrane potential $(0.1 \pm 0.9 \mathrm{mV} ; n=9)$ and a small but nonsignificant increase in input resistance (116 \pm $17 \% ; n=9$ ), possibly as a result of dialysis during whole-cell patch recordings. The amplitude of depolarizing current pulses necessary to elicit an action potential increased 13-fold (13.0 \pm 4.1; $n=15 ; p<0.05)$ in AlstR-transfected cells, indicating greatly reduced excitability (Fig. $2 A 3$ ). Control cells, in contrast, showed no change in excitability $(1.1 \pm 0.1 ; n=9)$. These results indicate that AL can be used to, in effect, silence AlstR-transfected cortical neurons. Moreover, these results suggest that the effects of
AL are specific and that the physiological properties of untransfected neurons remain unchanged.

\section{Reversibility of AL-induced effects}

In a subset of AlstR-transfected cells $(n=8)$ we tested whether, and how quickly, silencing was reversible. The effects of AL typically subsided within 15 min after AL removal (Fig. 1A2). At a perfusion rate of $\sim 200 \mu \mathrm{l} / \mathrm{min}$ and a bath volume of $\sim 3 \mathrm{ml}$ of saline, this time was approximately equivalent to one exchange of the bath volume. At 15 min after initiation of AL washout, the membrane potential of AlstR-transfected cells returned to within $4.4 \pm 1.1 \%$ of its original value (Fig. 2 B1; Table 1). Input resistance and excitability also returned to approximately original values (Fig. 2B2,3; Table 1). Considering the limitations for efficiently removing AL by perfusion, it is likely that the effects of AL could, in principle, be reversed even faster.

\section{DISCUSSION}

Together, these experiments demonstrate the potential of AlstR/AL as a genetic system for selectively and quickly hyperpolarizing mammalian neurons in a reversible manner. Given the large decreases in excitability that we observed in our in vitro preparation, it is likely that AlstR/AL will also be able to, in effect, silence cortical neurons under physiological conditions in vivo.

\section{Quickly reversible silencing versus transcriptionally regulated inactivation}

The AlstR/AL system represents an important new tool among the growing number of techniques for neuronal inactivation. First, because AlstR is not known to be activated by mammalian ligands (Birgül et al., 1999), its constitutive expression in the mammalian brain should not result in complications related to long-term plasticity or developmental compensation mechanisms. Second, the activation of the receptor by its ligand allows for much faster manipulations of neural activity than can be achieved by genetically regulated methods of silencing, such as the inducible expression of $\mathrm{K}+$ channels (Johns et al., 1999; Zemelman and Miesenböck, 2001). Although transcriptional inactivation methods are well suited for long-term silencing of neurons (e.g., in developmental studies), the high degree of selectivity and temporal control provided by ligand-induced silencing via the AlstR/AL system is uniquely suited for switching identified populations of neurons off and on quickly (e.g., during in vivo neurophysiological experiments and in awake behaving animals).

The advantages and disadvantages of each technique have to be weighed for each application. For example, the sustained increase in $\mathrm{K}+$ conductance associated with slow transcriptional regulation of $\mathrm{K}+$ channel expression may lead to irreversible silencing and cell death in some systems (Nadeau et al., 2000). AL-induced silencing, in contrast, is quickly turned on and off, which should limit any cytotoxic effects associated with increased $\mathrm{K}+$ conductance. For long-term silencing, however, the AlstR/AL system may not be useful. Like other G-protein-coupled receptors, it is likely that the AlstR may be desensitized or internalized with prolonged exposure to its ligand.

The effectiveness of inactivation by the AlstR/AL system, in some cases, may also be dependent on the level of endogenous GIRK channel expression (e.g., in a given cell type or at an early developmental stage). In such systems, cotransfection with GIRK channel subunits, as in this study, may be necessary to effectively inactivate neurons using AlstR/AL. The requirement to coexpress GIRK channels in such cases should not preclude the effective use of the AlstR/AL system. The in vitro expression of 


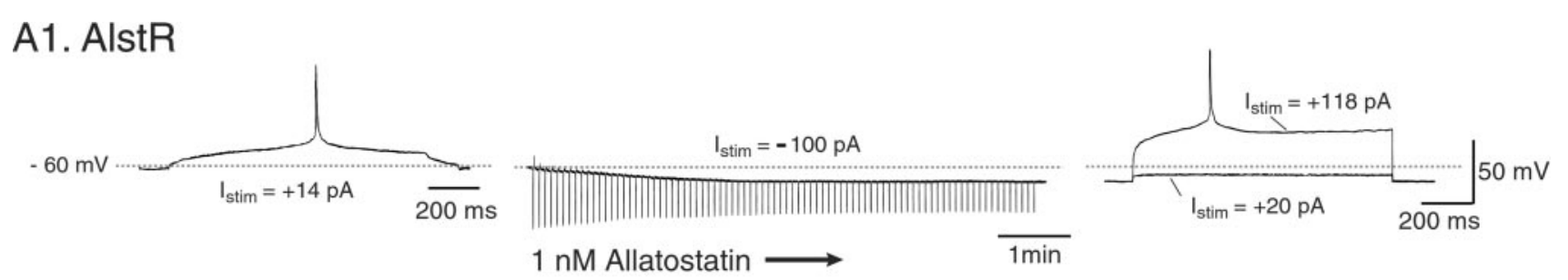

\section{A2. Wash out}
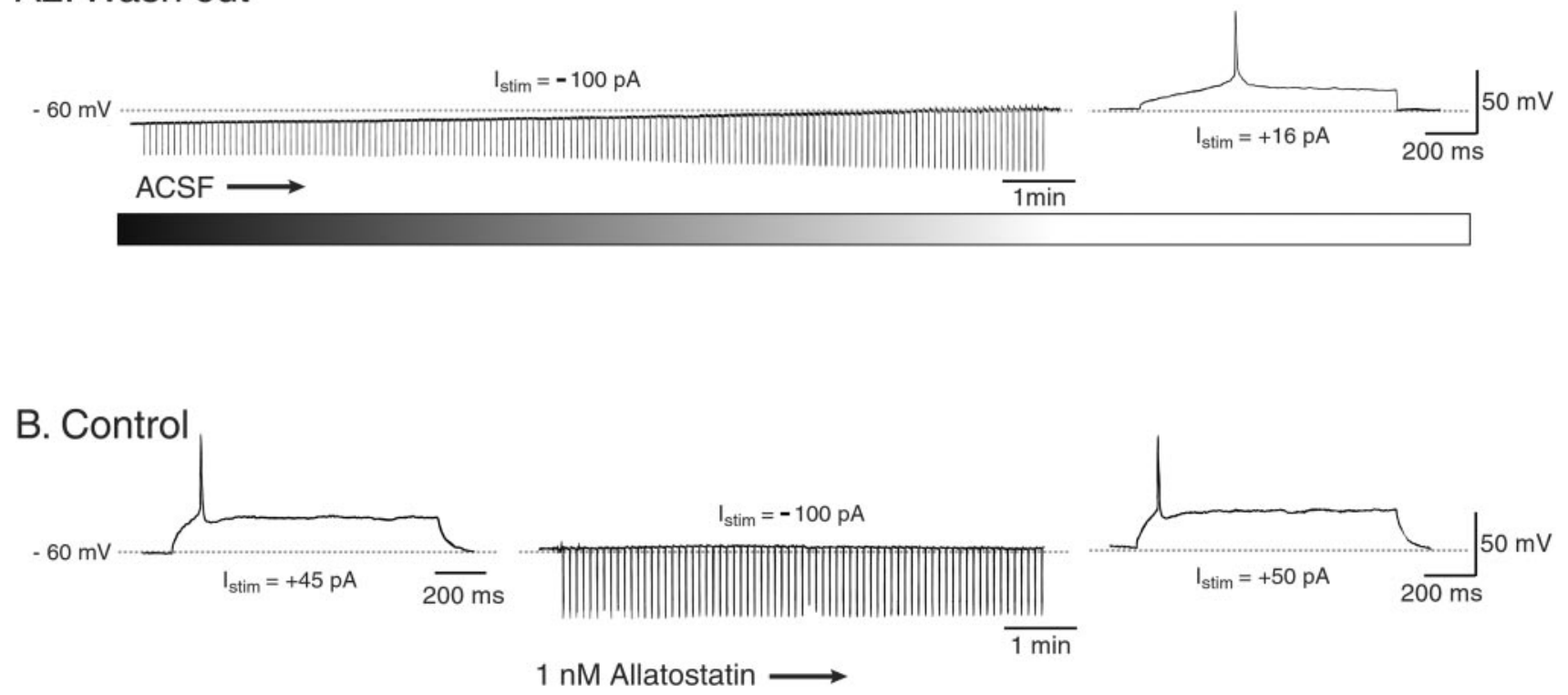

Figure 1. Silencing of cortical neurons with the AlstR/AL receptor/ligand system. A1, The spike threshold of a representative AlstR-transfected neuron was determined by a series of depolarizing current pulses $\left(I_{\text {stim }}, 1 \mathrm{sec}\right.$ duration; left panel) before addition of allatostatin to the bath ( gradually shaded bar). In this example, the spike threshold was found to be at $+14 \mathrm{pA}$. Before and after the onset of perfusion with $1 \mathrm{~nm}$ AL, input resistance was monitored by hyperpolarizing current pulses at $5 \mathrm{sec}$ intervals (middle panel). Input resistance and resting membrane potential decreased within minutes of AL application. The amount of current necessary to elicit an action potential in the presence of AL (+118 pA) was greatly increased with respect to the initial values (right panel). A2, The effects of AL were reversible over the course of several minutes by washing out AL with normal ACSF. Input resistance, membrane potential (left panel), and spike threshold (right panel) returned to approximately initial values after a perfusion time approximately equivalent to the time required for the exchange of one bath volume (see Results). $B$, Input resistance, membrane potential, and spike threshold of control neurons were unaffected by application of AL.

\section{Table 1. Electrophysiological properties of AlstR-transfected and control neurons before and during application of AL}

\begin{tabular}{|c|c|c|c|c|c|c|c|c|c|}
\hline & \multicolumn{3}{|c|}{ Membrane potential (mV) } & \multicolumn{3}{|c|}{ Input resistance $(\mathrm{M} \Omega)$} & \multicolumn{3}{|c|}{ Threshold current (pA) } \\
\hline & ACSF & $1 \mathrm{~nm} \mathrm{AL}$ & Wash & ACSF & $1 \mathrm{~nm} \mathrm{AL}$ & Wash & ACSF & $1 \mathrm{~nm} \mathrm{AL}$ & Wash \\
\hline Control $(n=9)$ & $-59.8(1.0)$ & $-59.8(1.2)$ & - & $448(74)$ & $472(54)$ & - & $41.4(10.2)$ & $44.2(11.6)$ & - \\
\hline $\operatorname{AlstR}(n=15)$ & $-61.2(0.9)$ & $-67.9(1.0)^{* * *}$ & See subset & $455(50)$ & $197(29)^{* * *}$ & See subset & $28.9(3.2)$ & $321.3(76.1)^{*}$ & See subset \\
\hline AlstR subset $(n=8)$ & $-62.0(1.2)$ & $-70.1(1.1)^{* *}$ & $-62.4(1.8)$ & $493(71)$ & $147(20)^{* *}$ & $591(185)$ & $26.5(3.7)$ & $452.3(95.1)^{*}$ & $54.0(27.0)$ \\
\hline
\end{tabular}

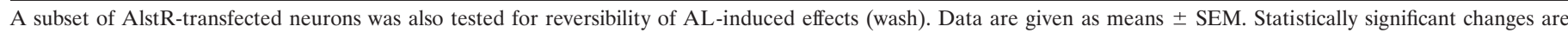
indicated as follows: ${ }^{*} p<0.05 ;{ }^{* *} p<0.001 ;{ }^{* * *} p<0.0001$.

GIRK subunits in cortical neurons of the neonatal ferret visual cortex did not affect the membrane potential or survival of those neurons compared with EGFP-transfected neurons (data not shown). In any case, we expect that these limitations will not be common in the application of the AlstR/AL system to adult brain tissue, because endogenous expression of GIRK channels is common to the great majority of adult mammalian brain areas (Karschin et al., 1996). However, it will be necessary for any given system to determine whether the neurons to be inactivated express GIRK channels or are inactivated by drugs (e.g., baclofen) whose effects are mediated by GIRK channels. 


\section{SELECTIVITY}
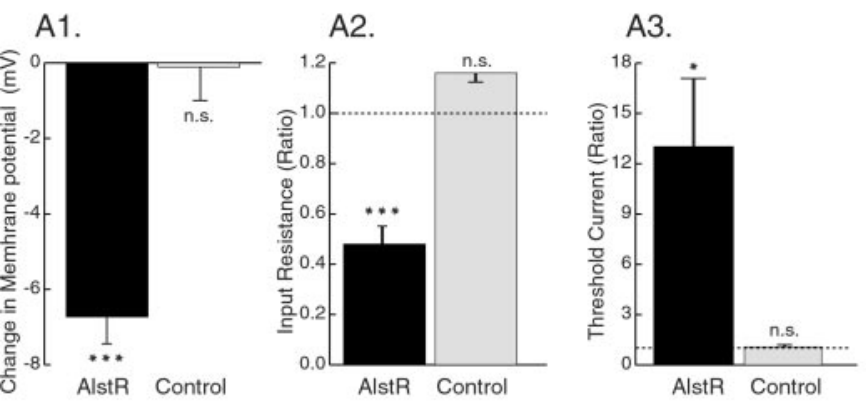

\section{REVERSIBILITY}

B1.

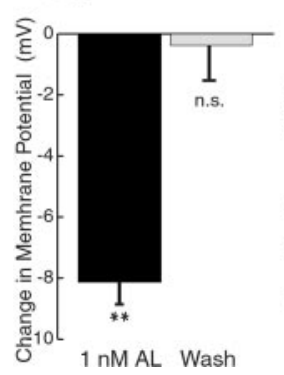

B2.

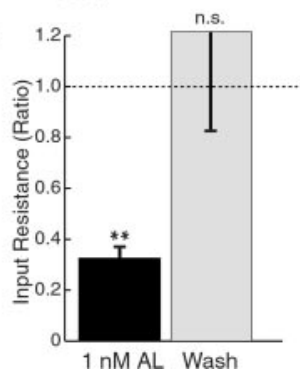

B3.

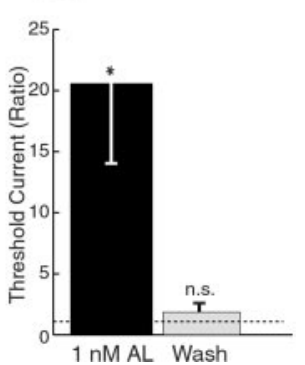

Figure 2. Selectivity and reversibility of AL-induced effects. A1, Effect of AL on membrane potential in AlstR-transfected $(n=15$; black bar $)$ and control neurons $(n=9$; light bar $)$. AL produced a significant decrease in membrane potential in AlstR-transfected neurons $(-6.7 \pm 0.7 \mathrm{mV}$; $\left.*_{* *} p<0.0001\right)$. Control neurons showed no change $(0.1 \pm 0.9 \mathrm{mV}) . A 2$, Ratio of input resistance before and after application of $1 \mathrm{~nm} A \mathrm{~L}$ in AlstR-transfected and control neurons. Input resistance decreased to $48 \pm 7 \%$ of the original value $(* * * p<0.0001)$ for AlstR-transfected neurons $(p<0.001)$, but control neurons were unaffected $(116 \pm 17 \%)$. $A 3$, The ratio of spike threshold (current amplitude necessary to elicit an action potential) before and after application of $1 \mathrm{~nm}$ AL in AlstRtransfected and control neurons. Spike threshold increased 13-fold for AlstR-transfected neurons $(1300 \pm 410 \% ; p<0.05)$, but control neurons were unaffected $(110 \pm 10 \%)$. B1, After removal of AL from the bath, the decrease in membrane potential induced by $1 \mathrm{nM} A L$ for a subset of eight AlstR-transfected neurons tested $(-8.1 \pm 0.7 \mathrm{mV} ; p<0.001)$ recovered to its original value $(-0.4 \pm 1.1 \mathrm{mV})$. $B 2$, Input resistance also returned from reduced levels $(33 \pm 43 \% ; p<0.001)$ to approximately original values $(122 \pm 39 \%)$. B3, The reversal of AL-induced effects on membrane potential and input resistance was accompanied by a recovery of excitability, as measured by the current amplitude for eliciting an action potential, from $2058 \pm 654 \%(p<0.05)$ to approximately original values $(186 \pm 75 \%) .{ }^{* * *} p<0.0001 ;{ }^{* *} p<0.001 ;{ }^{*} p<0.05 . n . s$., Not significant. Dotted lines indicate $100 \%$ (no change).

\section{Targeted delivery of "silencing genes"}

Techniques for delivering AlstR to targeted cell types are currently being developed using cell type-specific promoters to drive the expression of AlstR. Cell type-specific promoters have been used successfully in transgenic mice to restrict the expression of transgenes to brain areas and defined neuronal populations of interest (Mayford et al., 1996; Tsien et al., 1996; Yoshida et al., 2001; Zemelman and Miesenböck, 2001). In combination with viral delivery methods that are currently being developed in this and other laboratories, cell type-specific expression could also be achieved in animals that are not amenable to transgenic approaches (McCown et al., 1996; Ehrengruber et al., 2001).

\section{Ligand application}

Additional experiments will have to explore the best way to administer allatostatin in vivo. For example, direct and local application of the peptide into brain areas of interest may be preferable to intravenous injection, because this should allow for greater temporal control over the onset and reversal of AL-induced effects.

The results presented here, together with recent improvements in targeting specific cell types in a variety of animal models, suggest that the AlstR/AL system can become a powerful tool for studying the contribution of defined populations of a particular neural cell type to information processing, cognition, and behavior.

\section{REFERENCES}

Arnold D, Feng L, Kim J, Heintz N (1994) A strategy for the analysis of gene expression during neural development. Proc Natl Acad Sci USA 91:9970-9974.

Birgül N, Weise C, Kreienkamp H-J, Richter D (1999) Reverse physiology in Drosophila: identification of a novel allatostatin-like neuropeptide and its cognate receptor structurally related to the mammalian somatostatin/galanin/opioid receptor family. EMBO J 18:5892-5900.

Chen S-C, Ehrhard P, Goldowitz D, Smeyne RJ (1997) Developmental expression of the GIRK family of inward rectifying potassium channels: implications for abnormalities in the weaver mutant mouse. Brain Res 778:251-264

Coward P, Wada HG, Falk MS, Chan SDH, Meng F, Akil H, Conklin BR (1998) Controlling signaling with a specifically designed $\mathrm{G}_{\mathrm{i}}$-coupled receptor. Proc Natl Acad Sci USA 95:352-357.

Dantzker J, Callaway EM (1998) The development of local, layerspecific visual cortical axons in the absence of extrinsic influences and intrinsic activity. J Neurosci 18:4145-4154.

Dascal N (1997) Signalling via the G protein-activated K+ channels. Cell Signal 9:551-573.

Dascal N, Schreibmayer W, Lim NF, Wang W, Chavkin C, DiMagno L, Labarca C, Kieffer BL, Gaveriaux-Rugg C, Trolliger D, Lester HA, Davidson N (1993) Artrial G protein-activated K channel: expression cloning and molecular properties. Proc Natl Acad Sci USA 90:10235-10239.

Ehrengruber MU, Hennou S, Büeler H, Naim HY, Déglon N, Lundstrom K (2001) Gene transfer into neurons from hippocampal slices: comparison of recombinant semliki forest virus, adenovirus, adenoassociated virus, lentivirus, and measles virus. Mol Cell Neurosci 17:855-871

Johns DC, Marx R, Mains RE, O’Rourke B, Marbán E (1999) Inducible genetic expression of neuronal excitability. J Neurosci 19:1691-1697.

Karschin C, Dißmann E, Stühmer W, Karschin A (1996) IRK(1-3) and GIRK(1-4) inwardly rectifying K channel mRNAs are differentially expressed in the adult rat brain. J Neurosci 16:3559-3570.

Katz LC (1987) Local circuitry of identified projection neurons in cat visual cortex brain slices. J Neurosci 7:1223-1249.

Lesage F, Duprat F, Fink M, Guillemare E, Coppola T, Lazdunski M, Hugnot JP (1994) Cloning provides evidence for a family of inward rectifier and G-protein coupled $\mathrm{K}+$ channels in the brain. FEBS Lett 353:37-42.

Mark DM, Herlitze S (2000) G-protein mediated gating of inwardrectifier K+ channels. Eur J Biochem 267:5830-5836.

Mayford M, Bach ME, Huang YY, Wang L, Hawkins RD, Kandel ER (1996) Control of memory formation through regulated expression of a CaMKII transgene. Science 274:1678-1683.

McAllister AK, Lo DC, Katz LC (1995) Neurotrophins regulate dendritic growth in developing visual cortex. Neuron 15:791-803.

McCown TJ, Xiao X, Li J, Breese GR, Samulski RJ (1996) Differential and persistent expression patterns of CNS gene transfer by an adenoassociated virus (AAV) vector. Brain Res 713:99-107.

Nadeau H, McKinney S, Anderson DJ, Lester HA (2000) ROMK1 (Kir1.1) causes apoptosis and chronic silencing of hippocampal neurons. J Neurophysiol 84:1062-1075.

Redfern CH, Coward P, Degtyarev MY, Lee EK, Kwa AT, Hennighausen L, Bujard H, Fishman GI, Conklin BR (1999) Conditional expression and signaling of a specifically designed Gi-coupled receptor in transgenic mice. Nat Biotechnol 17:165-169.

Tsien JZ, Chen DF, Gerber D, Tom C, Mercer EH, Anderson DJ, Mayford M, Kandel ER, Tonegawa S (1996) Subregion- and cell typerestricted gene knockout in mouse brain. Cell 87:1317-1326.

Yoshida K, Watanabe D, Ishikane H, Tachibana M, Pastan I, Nakanishi S (2001) A key role of starburst amacrine cells in originating retinal directional selectivity and optokinetic eye movement. Neuron 30:771-780.

Zemelman BV, Miesenböck G (2001) Genetic schemes and schemata in neurophysiology. Curr Opin Neurobiol 11:409-414. 